University of Windsor

Scholarship at UWindsor

\title{
Efficacy of $\mathrm{NaCl}$ brine for treatment of ballast water against freshwater invasions
}

Tony Nan-Chun Wang

University of Windsor

Follow this and additional works at: https://scholar.uwindsor.ca/etd

\section{Recommended Citation}

Wang, Tony Nan-Chun, "Efficacy of $\mathrm{NaCl}$ brine for treatment of ballast water against freshwater invasions" (2011). Electronic Theses and Dissertations. 369.

https://scholar.uwindsor.ca/etd/369

This online database contains the full-text of PhD dissertations and Masters' theses of University of Windsor students from 1954 forward. These documents are made available for personal study and research purposes only, in accordance with the Canadian Copyright Act and the Creative Commons license-CC BY-NC-ND (Attribution, Non-Commercial, No Derivative Works). Under this license, works must always be attributed to the copyright holder (original author), cannot be used for any commercial purposes, and may not be altered. Any other use would require the permission of the copyright holder. Students may inquire about withdrawing their dissertation and/or thesis from this database. For additional inquiries, please contact the repository administrator via email (scholarship@uwindsor.ca) or by telephone at 519-253-3000ext. 3208. 
Efficacy of $\mathrm{NaCl}$ brine for treatment of ballast water against freshwater invasions

By

Tony Wang

\begin{abstract}
A Thesis
Submitted to the Faculty of Graduate Studies through the Great Lakes Institute for Environmental Research in Partial Fulfillment of the Requirements for the Degree of Master of Science at the University of Windsor
\end{abstract}

Windsor, Ontario, Canada

2010

(C2010 Tony Wang 
Efficacy of $\mathrm{NaCl}$ brine for treatment of ballast water against freshwater invasions

By

Tony Nan-Chun Wang

APPROVED BY:

Dr. Lynda Corkum
Department of Biological Sciences

Dr. Hugh Maclsaac, Co-supervisor

Great Lakes Institute for Environmental Research

Dr. Sarah Bailey, Co-supervisor

Department of Fisheries and Oceans Canada

Dr. Doug Haffner, Chair of Defense

Great Lakes Institute for Environmental Research

Sept 16, 2010 


\section{Author's Declaration of Originality}

I hereby certify that I am the sole author of this thesis and that no part of this thesis has been published or submitted for publication.

I certify that, to the best of my knowledge, my thesis does not infringe upon anyone's copyright nor violate any proprietary rights and that any ideas, techniques, quotations, or any other material from the work of other people included in my thesis, published or otherwise, are fully acknowledged in accordance with the standard referencing practices. Furthermore, to the extent that I have included copyrighted material that surpasses the bounds of fair dealing within the meaning of the Canada Copyright Act, I certify that I have obtained a written permission from the copyright owner(s) to include such material(s) in my thesis and have included copies of such copyright clearances to my appendix.

I declare that this is a true copy of my thesis, including any final revisions, as approved by my thesis committee and the Graduate Studies office, and that this thesis has not been submitted for a higher degree to any other University or Institution. 


\section{Abstract}

Currently, all transoceanic vessels entering the Great Lakes must perform ballast water exchange or saltwater flushing. Non-compliant vessels presently have limited and often costly and/or time consuming alternatives available. Treatment with sodium chloride $(\mathrm{NaCl})$ brine as an alternative ballast water management option was examined here.

Six shipboard trials were conducted - three trials each on vessels with residual ballast water and with full ballast tanks - under operational conditions to determine the efficacy of brine ballast water treatment. Results indicate that brine is highly effective at reducing viability of zooplankton.

It took 25 and 5 hours to achieve $100 \%$ mortality in ballasted and residual ballast vessels respectively. Brine distributed well in tanks, however, vessel movement was essential to ensure thorough mixing. This method of ballast treatment appears to be cost-effective and safe and it could be implemented to reduce risk of new invasions in the Great Lakes. 
Dedicated to my parents Michael and Grace

For all their support and encouragement 


\section{Acknowledgements}

I would like to thank my advisors, Drs. Sarah Bailey and Hugh Maclsaac, for their support throughout the planning and implementation of my studies. Their assistance and comments during the preparation of this thesis were invaluable. I am also grateful that they supported my travel to many conferences, enabling me to develop my presentation skills and network with international colleagues.

I would like to acknowledge Dr. David Reid, Dr. Tom Johengen, Captain Philip Jenkins, Chris Wiley, Matthew Deneau, Jocelyn Gerlofsma, and Johanna Bradie for their assistance in the field. Without their gracious help, my experiments would not have been possible.

Finally, I would like to acknowledge my parents, Michael and Grace, and my partner, Lauren, for their support and encouragement in my work.

The support and encouragement I received from my friends, my labmates, and my officemates, was very motivational and critical to the timely preparation of this thesis. 
Table of Contents

Declaration of Originality

iii

Abstract iv

Dedication v v

Acknowledgments vi

List of Tables viii

List of Figures $\quad$ ix

Chapter 1: General Introduction 1

Chapter 2: Efficacy of $\mathrm{NaCl}$ brine for treatment of ballast water $\begin{array}{ll}\text { against freshwater invasions } & 10\end{array}$

Chapter 3: General Discussion 25

$\begin{array}{ll}\text { References } & 40\end{array}$

Appendix 1

Vita Auctoris $\quad 56$ 


\section{List of Tables}

Table 1. IMO's D-2 standard for maximum density of organisms discharged after ballast water treatment

Table 2. Experiment locations, date, and amount of brine applied

Table 3. Measurements of temperature, conductivity, dissolved oxygen, and $\mathrm{pH}$ in control and treatment tanks for the three ballast-on-board shipboard trials

Table 4. ANOVA with repeated measures demonstrating the effects of brine on live zooplankton abundance

Table 5. Maximum permissible chloride values permitted in ballast water discharge by each of the eight Great Lakes states and Ontario 35 


\section{List of Figures}

Figure 1. Changes in salinity $( \pm \mathrm{SE})$ following addition of brine into treatment tank for the three ballasted vessels

Figure 2. Changes in $(A)$ mean $( \pm S E)$ live abundance of zooplankton and $(B)$ mean $( \pm S E)$ proportion of total viable zooplankton in control and treatment tanks for ballasted tank experiments following brine treatment

Figure 3. : Changes in mean $( \pm S E)$ salinity over time in control and treatment tanks in ballast residuals experiments

Figure 4. Changes in $(A)$ mean $( \pm S E)$ live abundance of zooplankton and $(B)$ mean $( \pm S E)$ proportion of total viable zooplankton incontrol and treatment tanks for ballast residuals experiments following brine application 


\section{CHAPTER1: GENERAL INTRODUCTION}

Biological invasions are a leading cause of species extirpation and extinction, and contribute to global homogenization wherein native species are replaced by non-indigenous species (NIS) (McKinney and Lockwood, 1999; Rahel, 2002; Drake and Lodge, 2004). A NIS is a species that has established outside of its native habitat range. The impacts of biological invasions are evident on almost all landmasses and in aquatic environments (Bright, 1999; Olden et al., 2008; Piola et al., 2009).

Zooplankton are a major concern when it comes to freshwater species invasions, especially since the group is incredibly diverse, capable of rapid reproduction, and have strong ecological effects (Machida et al., 2009). Zooplankton can be transported and released in large numbers through ships' ballast water. Choi et al. (2005) found the abundance of zooplankton on bulk carriers in San Francisco Bay averaged 374 individuals $\mathrm{m}^{-3}$ in summer months (June-September). About 1,000 to 800,000 individuals $\mathrm{m}^{-3}$ may be transported in unmanaged ballast water and subsequently be released with the discharge of ballast water (Wonham et al., 2001; Verling et al., 2005; McCollin et al., 2008). Not only can NIS greatly affect the environment, they can also negatively impact the economy by affecting equipment maintenance costs and tourism revenue. The cost associated with NIS in Canada alone exceeds $\$ 13$ billion year ${ }^{-1}$ (Colautti et al., 2006a). It is therefore necessary to prevent and stop NIS invasions.

Invasive species in the Great Lakes 
At least 180 aquatic NIS have established in the Laurentian Great Lakes, and the resulting impacts of some species have been severe (Ricciardi, 2001; Duggan et al., 2003; Ricciardi, 2006). From 1840 to 2006, 13 of the NIS established in the Great Lakes were zooplankton species (NOAA, 2006). This may seem like a small number but NIS can have devastating effects on recipient habitats. An example of a species introduced through ballast water that had negative impact on the environment is Bythotrephes longimanus. It is native to Eurasia and was first found in Lake Huron in 1984, but it has since spread to other Great Lakes (Sprules et al., 1990; Hovius et al., 2007). These predatory cladocerans prefer large zooplankton as prey. Defensive mechanisms of Daphnia, such as tailspines and helmets, are not effective against these new predators (Schulz and Yurista, 1999) and Bythotrephes may prey on native predatory species, such as Mesocyclops and Leptodora, to near extinction (Hovius et al., 2007). Generalists like Bythotrephes have the potential to consume a large portion of zooplankton production (Yurista and Schulz, 1995; Foster and Sprules, 2010).

Invasion through ballast water

Approximately 7,000 species are transported in ballast water around the world each day by commercial vessels (Carlton, 1999) and the movement of ballast water is one of the most important vectors for aquatic NIS transfer today (Ruiz et al., 1997). Some vessels contain much larger volumes of ballast water than previous generations of ships. Consequently, modern vessels can deliver 
more propagules at a faster rate than in the past, and thereby increase the propagule pressure associated with ballast water release.

The primary mechanisms of ship-mediated introductions include ballast water, ballast sediments, and biological fouling of ship hulls (Dodgshun et al., 2007). It is important to focus on ballast water rather than other ship-mediated pathways because NIS contained in the water column are more likely to be discharged from vessels than NIS or fouled on ship hulls. Sylvester and Maclsaac (2010) found that hull fouling posed little risk of species invasion to the Great Lakes because few freshwater organisms survive on hull surfaces after transit across the Atlantic Ocean.

Ships with "no-ballast-on-board" are often referred to as NOBOB ships. These ships are loaded with cargo so ballast water is not needed for balance and trim (Transport Canada, 2010). Ballast pumps can remove most of the water out of the tanks but small amounts of water and sediment will typically remain on board as residuals, as in the case of NOBOB tanks (Boylston, 1996). The layer of unpumpable water and sediment may become a more or less permanent layer on the bottom of the tanks supporting many benthic life forms of all life stages.

There are four basic stages to biological invasion: transport, introduction, establishment, and spread (Colautti and Maclsaac, 2004). During the transport stage, NIS must be loaded into the vessel and survive the physical transfer from donor region to recipient region. In the second stage, the NIS that survived the trip must be discharged into the recipient ecosystem. Those discharged must survive the physical and chemical conditions of the new habitat to establish a 
reproductive colony. Some individuals will be in such poor health after the release that they cannot establish a reproducing population. The fourth stage begins when the established population grows and individuals begin to disperse and expand the geographical range in the recipient habitat. NIS may cause ecological or economic harm through interactions, such as predation or competition with native species, and may subsequently affect the economy (e.g. fish industries) (Lockwood et al., 2007). Typically, it is only when the NIS is widespread and abundant that it will cause harm to the environment or to the economy (Lockwood et al., 2007).

There are three filters that may affect the transition of NIS between stages: propagule pressure, physico-chemical factors, and community interactions (Colautti and Maclsaac, 2004; Colautti et al., 2006b). Propagule pressure is a measure of introduction effort and includes three main components: propagule size, propagule number, and the condition of propagules (Lockwood et al., 2007; Simberloff, 2009). Propagule size is the number of individuals in a release event and propagule number is the number of release events. As propagule size and number increase, the probability of successful invasion also increases because as more individuals are introduced into one place, it becomes more likely that some individuals will be successful in establishing colonies and thrive in the new environment (Kolar and Lodge, 2001; Lockwood et al., 2007; Sagata and Lester, 2008). The condition of propagules also contributes to the success rate of biological invasions in that the healthier the invaders are, the more likely that they will survive long enough to find food and suitable mates and contribute to the 
success rate of establishment (Simberloff, 2009). Propagule pressure acts on all four stages of invasion and it aids the transition of NIS to subsequent stages (Colautti and Maclsaac, 2004).

Physico-chemical factors also impact the ability of NIS to transition through the stages of an invasion (Jones and Ricciardi, 2005; Leung and Mandrak, 2007; Cordell et al., 2010). If factors such as temperature or $\mathrm{pH}$ are not tolerable by the NIS, then the NIS may not survive long enough to establish a reproducing population.

Community interactions act on stages two, three, and four (Colautti and Maclsaac, 2004). NIS that survived the transport stage will interact with the native species or other established NIS, after the release. The widely quoted 'Tens rule' states that about $10 \%$ of all introduced NIS successfully establish and about $10 \%$ of those established species become invasive (Williamson and Brown, 1986). Karatayev et al. (2009) showed that successful NIS are not just random subsamples of species drawn from a native region, but are more robust than the natives and have greater tolerance to pollution. Some examples of harmful invasive species in the Great Lakes are zebra mussels (Dreissena polymorpha), round gobies (Neogobius melanostomus), and predatory cladocerans such as Cercopagis pengoi and Bythotrephes longimanus.

Prevention of NIS introductions effectively eliminates the need to develop NIS control and management programs for stages two, three, and four. Therefore, it is important to focus on eliminating NIS in ballast water before they are discharged. 


\section{Ballast water regulations}

Since 1993, transoceanic vessels with filled ballast tanks have been required to perform ballast water exchange (BWE) with highly saline, open ocean water. Current Canadian BWE regulations state that the exchanged ballast water must have a final salinity of at least 30 parts per thousand (\%o) and that the saline water must be taken from mid-ocean at least 200 nautical miles offshore and in depth of at least 2000 meters (Transport Canada, 2010). Despite implementation of these regulations, the number of NIS introductions did not appear to decline (Duggan et al., 2003; Ricciardi, 2006). The International Maritime Organization's (IMO) D-1 regulation for BWE requires vessels to conduct at least $95 \%$ volumetric exchange (IMO, 2010). In addition, the IMO's D-2 ballast water performance standard was proposed (but not yet implemented) to reduce the chance of successful invasion by reducing propagule pressure for specific size classes and indicator bacteria in discharged ballast water (Table 1).

BWE can greatly reduce the abundance of freshwater species by purging them from tanks (Gray et al., 2007), and the high salinity level of sea water should induce physiological stress on organisms remaining in the tanks (Wonham et al., 2005; Ellis and Maclsaac, 2009). However, some vessels cannot comply or can only partially comply with the regulations due to various factors such as weather conditions and ship safety.

Even though greater efforts by researchers to identify invasive species may be a factor in an apparent increased rate of discovery of NIS over the past 
17 years, continued discoveries of new NIS led some people to question the effectiveness of BWE (Duggan et al., 2003). Ricciardi (2006) reported that recently introduced NIS to the Great Lakes are mostly euryhaline benthic invertebrates, and suggested that the Great Lakes are still at risk of more NIS invasions because these NIS may have the ability to survive BWE.

\section{Treatment of ballast water}

Besides BWE, various methods for eliminating NIS in the ballast tanks have been suggested, including biocide, heat, and ultraviolet treatments. There are at least 41 ballast water treatment systems around the world that are at various stages of development and approval (Lloyd's Register, 2010). Most treatment technologies are still in the experimental phase and will not be ready for implementation until around 2016 (California Environmental Protection Agency, 2002).

The filtration technology is perhaps the most environmentally-friendly method at removing organisms from ballast water but it must be coupled with other treatment(s), such as heat or UV radiation, to eliminate NIS quantitatively (California Environmental Protection Agency, 2002; Kazumi, 2007). Preliminary observations showed that biocides are effective at treating ballast water (California Environmental Protection Agency, 2002; Gavand et al., 2007; Kazumi, 2007) but appropriate disposal or neutralization must be considered (California Environmental Protection Agency, 2002; Kazumi, 2007). Research has demonstrated that deoxygenation, UV radiation, and heat treatment are not 
effective against zooplankton resting eggs but they are effective against organisms in other life stages (Tamurri et al., 2002; California Environmental Protection Agency, 2002; Kazumi, 2007; Raikow et al., 2007).

\section{Using brine as a treatment method}

The addition of $230 \%$ sodium chloride $(\mathrm{NaCl})$ brine has been proposed as a treatment method for non-compliant vessels by Jenkins (2007). This method of killing ballast water organisms has similar rationale as BWE in that the brine will cause high osmotic stress to the organisms and thus induce mortality. BWE that achieved a final salinity of $30 \%$ in ballast tanks has an efficiency of $>99 \%$ mortality for freshwater organisms (Gray et al., 2007), therefore, treatment using brine at $230 \%$ is expected to be at least as effective as BWE.

Brine is readily available around the Great Lakes basin and is costeffective (Jenkins, 2007). Jenkins (2007) estimated that the cost of brine treatment per vessel could range between $\$ 5,200$ and $\$ 7,200$. The cost includes transportation of the brine, the brine itself, and labour (loading and unloading). Most of the cost of brine treatment is associated with delivery, therefore, to lower the cost, it may be possible to install "brine stations" at various ports for quick delivery of brine to vessels.

Bradie et al. (2010) demonstrated that exposure to $\mathrm{NaCl}$ brine at $115 \%$ concentration was highly toxic for a wide variety of aquatic invertebrates that may be transported in ballast water. Treatment at $77 \%$ was also highly toxic, however, it took a longer time to fully eliminate invertebrates (Bradie et al., 2010). The 
ability to completely mix brine and ballast water in ballast tanks under operational conditions was highlighted as a potential impediment to this management strategy.

This thesis describes the first comprehensive trials to evaluate the efficacy of $\mathrm{NaCl}$ brine as a tool to prevent introductions of aquatic invasive species via ballast water. This study evaluates how well $\mathrm{NaCl}$ brine is at eliminating organisms in ballast tanks on transoceanic vessels and also evaluates how well brine mixes in tanks under normal operational conditions. 


\section{CHAPTER 2: EFFICACY OF NaCI BRINE FOR TREATMENT OF BALLAST WATER AGAINST FRESHWATER INVASIONS}

\section{Introduction}

Up to five billion $\mathrm{m}^{3}$ of ballast water, carrying an estimated 7,000 species, are transported daily around the world by commercial vessels (Carlton, 1999; Tsolaki and Diamadopoulos, 2010). Studies indicate that commercial vessels may transport 1,000 s to 100,000 s of individuals of zooplankton per $\mathrm{m}^{3}$ in ballast water (Wonham et al., 2001; Verling et al., 2005; McCollin et al., 2008). Propagule pressure theory indicates that the probability of successful establishment of introduced non-indigenous species (NIS) is directly proportional to the density of viable individuals introduced (Lockwood et al., 2005, 2007). Even though attenuation of propagule number is common for most biota during transit in a vessel's ballast tanks, commercial shipping and ballast water release has played a strong role in the introduction of NIS to novel habitats worldwide (Ruiz et al., 1997; Wonham et al., 2001). For example, 34 of 56 (61\%) aquatic NIS discovered in the Laurentian Great Lakes since the St. Lawrence Seaway opened in 1959 were introduced by shipping activities, including at least 10 zooplankton species (Kelly et al., 2009; NOAA, 2010).

Ballast water management systems, utilizing filtration, de-oxygenation, biocides, and/or ultraviolet treatment can minimize the risk of ship-mediated aquatic invasions by reducing propagule pressure. However, these systems will not be comprehensively deployed until approximately 2016 according to an 
International Maritime Organization (IMO) agreement and timeline (Tsolaki and Diamadopoulos, 2010; Lloyd's Register, 2010). Until then, ballast water exchange (BWE) and saltwater flushing are mandatory management practices used to prevent aquatic NIS introductions in the Great Lakes (Government of Canada, 2006; SLSDC, 2008). BWE involves discharging fully loaded ballast tanks while the ship is located in mid-ocean, and replacing this water with high salinity water to achieve $\geq 30$ parts per thousand (\%o) final salinity. Saltwater flushing, similar to BWE but with smaller volumes of water, is used for tanks containing only residual ballast water (i.e., no-ballast-on-board or NOBOB; see Bailey et al., 2010). The biological efficacy of BWE is variable for coastal marine habitats (Ruiz and Reid, $2007)$, though it appears to be highly effective (>99\%) against freshwater zooplankton (Gray et al., 2007). BWE and saltwater flushing reduce invasion risk by decreasing the number of individuals (propagule pressure) and number of species (colonization pressure) in ballast tanks by physical removal (i.e., purging). In addition, exposure to mid-ocean water may provide additional protection against fresh- and brackish-water taxa sensitive to osmotic stress (Santagata et al., 2008; Ellis and Maclsaac, 2009).

Though compliance with regulations is high, approximately $2 \%$ of ballast tanks are non-compliant upon arrival to the Great Lakes, indicating a need for alternative treatment methods (GLSBWWG, 2009). Currently, vessels can retain non-compliant ballast water on board throughout their operations on the Great Lakes or return to an approved offshore location to perform BWE and/or saltwater flushing. Canadian regulations allow for use of approved treatment technologies, 
however, no such technologies have been approved by Canada or the U.S.A. to date, except for in the States of Michigan and Washington (University of California, 2009). I propose here that sodium chloride $(\mathrm{NaCl})$ brine - hereafter called only 'brine' - be used as an alternative treatment method for non-compliant tanks. Brine, at $230 \%$ salinity, is presently used for de-icing roads during winter around the Great Lakes, and is relatively cheap and readily available (Jenkins, 2007). Laboratory experiments have demonstrated that brine kills both freshwater and oceanic zooplankton over a short time exposure (hours) when applied at a minimum concentration of 77\% (Santagata et al., 2009; Bradie et al., 2010). Here, I conduct shipboard experiments to determine if ballast water treatment with brine is effective under operational conditions. I test the toxic effect of brine exposure on freshwater invertebrates contained in large volumes and residual volumes of ballast water. Specifically, I test whether zooplankton in experimental tanks experience significantly higher mortality than in control tanks when exposed to brine.

\section{Methods}

\section{Study Site Description}

A total of six shipboard trials were conducted on vessels operating on the Laurentian Great Lakes. Three trials were conducted with filled tanks (ballast-onboard vessels) of transoceanic commercial bulk carriers between June and October 2009 during voyages from Toronto, ON to Thunder Bay, ON (Table 2). For each of the trials, paired upper-stool ballast tanks with identical design were 
filled with Great Lakes freshwater (0\%) at port in Toronto. One tank served as a control, which had no brine addition, while the other was later treated with brine; the control tank was filled completely while sufficient space was left in the experimental tank to accommodate subsequent addition of brine.

Three additional trials were conducted with residual ballast (no-ballast-onboard vessels) of domestic commercial tankers while moored in Sarnia, ON between November 2008 and December 2009 (Table 2). Paired double bottom ballast tanks of identical design were utilized for each trial, each containing residual Great Lakes freshwater $(0 \%)$. One tank served as a control with no brine addition, while the other was later treated with brine. Brine, at a concentration of $230 \%$, was delivered to vessels by tanker truck (Road Maintenance Equipment \& Services Inc., Cobourg, ON). Brine was pumped through a hose from the brine truck directly into the treatment ballast tanks. A flowmeter on the pump indicated the amount of brine pumped into tanks (Table 2).

\section{Assessment of brine distribution}

For ballasted tank trials, five self-recording programmable sondes, each with temperature, conductivity, optical dissolved oxygen, and depth sensors, were secured in the treatment tank. Sondes were positioned to cover a range of depths and horizontal coverage to quantify the extent of brine mixing within the tank. One sonde was installed in the control tank to monitor the same conditions. Conductivity sensors were calibrated with $\mathrm{NaCl}$ solutions ranging from $0-120 \%$ o prior to each deployment. Specific conductance was used to correct for 
temperature effects. A third order polynomial equation was calculated from each set of calibrations, for each sonde, to convert measured specific conductance to equivalent $\mathrm{NaCl}$ concentration (\%o). These empirical calibration curves were necessary to determine actual concentrations of brine present in tanks during experiments because the sondes are not calibrated specifically to $\mathrm{NaCl}$ and reported salinity values from the sondes at conductivities above $60 \mathrm{mS} \mathrm{cm}^{-1}$ are not accurate or within manufacturer specifications. In addition, specific conductance output of each sonde was checked post-experiment against a $44 \pm 1 \% \mathrm{NaCl}$ solution (as measured with a precision hand-held $\mathrm{NaCl}$ refractometer). All measurements were within $1 \%$ of the expected concentration. Dissolved oxygen sensors were calibrated against air saturation for each sonde prior to each deployment. Vertical profiles of the experimental tank were taken with a hand-held YSI unit at the same time zooplankton samples were collected.

For residual ballast experiments, the multi-parameter sondes could not be used owing to safety issues relating to battery-powered instruments around volatile cargo. Instead, water samples were taken from at least the three tank corner locations farthest from the location of brine addition for subsequent measurement of salinity using a digital salinity refractometer. Samples were collected approximately hourly, from both the top and bottom layer of ballast residuals using a plastic pipette, at the same time as collection of zooplankton samples.

Experimental Design - Ballasted Tanks 
To assess biological efficacy of brine treatment of ballasted tanks, zooplankton samples were collected from ballast water in both control and treatment tanks prior to the addition of brine and during the vessel transit following treatment at time points approximately $1 \mathrm{~h}, 6 \mathrm{~h}, 12 \mathrm{~h}, 24 \mathrm{~h}, 48 \mathrm{~h}$, and $72 \mathrm{~h}$ post-treatment. Consecutive, vertical (1.8-m depth) plankton net tows were taken with a 30-cm diameter, 40- $\mu \mathrm{m}$ mesh conical net through an opened deck hatch for the first two vessels; the number of net tows was based on the expected density of zooplankton in the ballast water, thus sample volume increased over time as the density of live animals in treatment tanks decreased (target of $\geq 25$ individuals per sample). As the upper stool tanks of the third vessel did not have deck hatches, samples were collected by lowering $1.27-\mathrm{cm}$ inner diameter high density polyethylene tubing, fitted with a stainless steel check valve, into the tank through the sounding tube. Approximately $50-\mathrm{L}$ of water was manually pumped to the deck surface at each sample time point, and filtered through the $40-\mu \mathrm{m}$ mesh plankton net. After initial samples were collected, brine $(230 \%)$ was added to the experimental tanks through opened deck hatches (first two vessels) or sounding tube (third vessel) at Port Weller, ON. Owing to the large volume of water in the tanks, it was not possible to add enough brine to achieve a final concentration of $77 \%$ for even the short time intervals suggested by previous studies (Jenkins, 2007; Santagata et al., 2009; Bradie et al., 2010). As a result, I decided to examine the effect of $45 \%$ brine treatment on zooplankton over multiple days. Ellis and Maclsaac (2009) showed that NIS already present in the Great Lakes experience $100 \%$ mortality when exposed to $30 \%$ seawater for 72 hours. A 
sufficient volume of brine was added to the tank to achieve the target concentration based on estimates of ballast volume provided by the ships' crew. Using a diesel pump, it took approximately one hour to apply the brine for each experiment and the volume added is shown in Table 2.

\section{Experimental Design - Residual Ballast}

The volume of residual ballast to be treated was estimated in consultation with the ships' crew so that brine could be added to the treatment tank in a 1:1 ratio to achieve a final target concentration of $115 \%$, based upon results of laboratory experiments (see Bradie et al. (2010) and recommendations by Jenkins (2007)). Using an intrinsically safe air-driven pump, which was slower than the diesel pump used for ballasted experiments, it took approximately one hour to apply the brine for each trial and the volume added is shown in Table 2.

To assess biological efficacy of brine treatment of residual ballast water, zooplankton samples were collected from residual ballast water in both control and treatment tanks prior to the addition of brine and following treatment with sampling conducted approximately hourly for up to 5 hours post-treatment. Zooplankton was collected by physically entering ballast tanks; a manual bilge pump was used to collect a measured volume of water in $25-\mathrm{L}$ plastic pails prior to filtration through a 40- $\mathrm{mm}$ mesh plankton net. A 1-L sample was initially collected to determine the density of zooplankton in tanks before each trial began. The volume sampled for each trial depended upon the initial density of zooplankton in residual ballast water (target of $\geq 25$ individuals per sample). 
Samples were collected at the location most distant from brine addition to the tank and a constant volume was sampled for all time points for both control and experimental tanks for each experiment.

\section{Viability Assessment}

Samples were filtered through a $40-\mu \mathrm{m}$ sieve to remove excess water and transferred to a petri dish for observation under a microscope immediately following collection (i.e. on board the vessel). Zooplankton viability was assessed through a combination of physical stimulation with a dissection probe and vital staining with 10-g/L neutral red (Tang et al., 2006). Samples in the petri dish were washed into a $250-\mathrm{ml}$ glass beaker using de-ionized water. One $\mathrm{ml}$ of neutral red solution was added to $100-\mathrm{ml}$ of zooplankton sample volume and left for $15 \mathrm{~min}$. Following staining, samples were repeatedly washed with tap water over a $40-\mu \mathrm{m}$ sieve to remove excess stain and transferred to a small, gridded petri dish for viability assessment. Neutral red stained most live zooplankton, and thus made the organisms much easier to find and check for body movement; however, as the stain was not $100 \%$ accurate, care was taken to assess all non-motile organisms that did not stain. Zooplankton which moved or twitched when stimulated by probe were considered live.

Assessment of zooplankton viability was completed within 30 minutes of sample collection. Live and dead zooplankton were divided into separate sample jars and preserved in $95 \%$ ethanol for later enumeration in the laboratory; dead individuals were removed from controls by pipette whereas live individuals were 
removed from treatment replicates. While the number of individuals transferred by pipette was recorded in the field, the live and dead sample fractions were enumerated more precisely back in the laboratory to determine abundance and proportion of live zooplankton in both control and treatment replicates. Owing to large numbers of zooplankton in some of the control 'live' fractions, three $0.5-\mathrm{ml}$ subsamples were taken from $50-\mathrm{ml}$ total sample volume to estimate abundance. Subsamples were drawn with replacement by Hensen-Stemple pipette, following thorough mixing to ensure uniform distribution of organisms. Samples that had less than 1,000 individuals were counted in entirety.

\section{Statistical Analysis}

To assess the efficacy of brine treatment based on changes in live zooplankton abundance, samples collected prior to brine treatment $\left(T_{0}\right)$ were compared to the final samples collected after brine treatment $\left(T_{1}\right)$. Following the methodology of Gray (2007), I calculated the percent change in live zooplankton abundance in each tank as:

$$
\% r=\left(T_{1} / T_{0}\right) * 100,
$$

where \%r represents the percent of zooplankton remaining after brine treatment, $T_{0}$ is the initial abundance, and $T_{1}$ is the final abundance measured after treatment. Identical calculations were conducted for control tanks $\left(\% r_{C}\right)$ at time 0 $\left(\mathrm{C}_{0}\right)$ and matching final time point $\left(\mathrm{C}_{1}\right)$. Using these values, I then calculated the efficiency of the brine as:

$$
B r_{E f f i c}=\left[\left(\% r_{C}-\% r_{T}\right) /\left(\% r_{C}\right)\right] * 100,
$$


where $\% r_{T}$ is the fraction remaining in the treatment tank and $\% r_{C}$ is the fraction remaining in the paired control tank. Paired sample t-tests were conducted to confirm that zooplankton abundance was similar in the control and treatment tanks at $\mathrm{T}_{0}$ for both $\mathrm{BOB}$ and $\mathrm{NOBOB}$ experiments. The abundance data was square-root transformed before analysis. One-way analysis of variance with repeated measures (RM-ANOVA) using SPSS 11.5 was utilized to determine if there were significant differences in abundance of live zooplankton between control tanks and treatment tanks following brine treatment.

\section{Results}

\section{Brine distribution}

Brine distributed well in ballasted tanks, especially after vessels were underway. The final uniform concentration of brine achieved was within $11-22 \%$ of the target value, reflecting difficulties estimating accurate volumes of ballast water inside tanks (Table 2). Measurements taken with the hand-held YSI unit showed that it took approximately 10 hours for the brine to reach uniform distribution in the tank center at the location of brine addition. However, records from multi-parameter sondes installed in tanks showed that stratification occurred during initial brine addition and uniform salinity was achieved 12-37 hours after brine addition (Figure 1); tanks were presumably stirred by rolling action after the vessels were underway. Different measurements taken from the instruments installed in ballast tanks are summarized in Table 3. All of the readings in the control and treatment tanks remained relatively constant through time, however, 
conductivity in treatment tanks increased following the addition of brine.

Brine mixed well with residual ballast water for trials 1 and 3 , however, incomplete mixing occurred during trial 2 with visible stratification of brine and freshwater residuals. Salinity in control tanks remained the same for the duration of the trials (Figure 3 ). The target concentration of $115 \%$ was reached or exceeded after 5 hours for all three trials (Table 2).

\section{Brine toxicity}

The paired sample t-tests showed that there were no significant differences in live zooplankton abundance between control and treatment tanks in either the ballasted tank experiment $(t=-0.234, p=0.837)$ or residual ballast experiment $(t=0.638, p=0.589)$ at the outset of the trials, before brine was applied. In ballasted tank trials, zooplankton consisted mainly of rotifers (Appendix 1). Other organisms such as annelids, molluscs, and insects/arachnids (i.e. spiders) were found in small numbers.

Abundance of live zooplankton in control tanks remained relatively consistent through time, however, abundance dropped significantly in treatment tanks following brine application $\left(F_{1,2}=335.02, p=0.003\right.$, ANOVA, Table 4). Complete mortality was observed at approximately 25 hours following brine treatment. While the total abundance of live zooplankton remain relatively constant in control tanks through time (Figure 2A), the proportion of viable zooplankton increased through time (Figure 2B).

Rotifers were also the most abundant taxon recorded in residual ballast 
trials (Appendix 1). Abundance of live zooplankton remained relatively consistent through time in control tanks, but dropped significantly following brine application $\left(F_{1,2}=168.05, p=0.006\right.$, ANOVA, Table 4). Both the proportion of total viable and the total abundance of zooplankton in control tanks remained relatively constant through time (Figure 4A-4B), which suggests that there was very little reproduction. Complete mortality of zooplankton in treatment tanks was observed at approximately 5 hours post-brine treatment.

Brine treatment was highly effective at killing freshwater zooplankton, with no live zooplankton recorded from the final samples collected for all six trials.

\section{Discussion}

The addition of brine appears to be a highly effective and operationally practical means for treatment of freshwater ballast. It took approximately 25 hours exposure to $45 \%$ brine (Figure 2), and 5 hours exposure to $115 \%$ brine, to effectively exterminate freshwater zooplankton (Figure 4) from ballast tanks having full or residual ballast on board, respectively. Brine appears to be an effective interim treatment for non-compliant vessels entering the Great Lakes that could be implemented immediately, although several challenges remain.

The two hour delay in mixing observed for one of the residual ballast trials was likely due to the static trim of the vessel and internal structure of the ballast tank. Internal tank structures, such as longitudinal members and bulkheads, may restrict natural mixing and diffusion for tanks that are completely filled as well as for tanks containing only residual ballast water. I observed that vessel movement, 
either as a result of wave action while underway or trim adjustments at berth, greatly facilitated mixing of brine in ballasted and residual ballast tanks, respectively. As a result, care must be taken to ensure complete mixing with ballast water to ensure maximal efficacy. Furthermore, when treating filled ballast tanks, the volume of brine needed to achieve the target concentration, particularly for treatment of freshwater ballast, must be considered since sufficient space must be available in tanks to accommodate the addition of brine. Ballast water may need to be divided among several tanks within a vessel to receive the brine volume without overflow of tanks.

While these tests indicated that brine treatment could completely eliminate freshwater zooplankton transported in ballast water, I acknowledge that individuals surviving brine treatment could have gone undetected due to the small sample sizes utilized in this study. Furthermore, additional tests examining a broader array of taxa are warranted since bacteria, viruses, and phytoplankton were not assessed during this study. I also did not examine efficacy against resistant taxa associated with ballast sediments, such as invertebrate dormant stages (Bailey et al., 2004, 2005; Briski et al., 2010). Previous studies have demonstrated that dormant stages of freshwater zooplankton can withstand exposure to high salinity levels and other chemical treatments (Bailey et al., 2004; Gray et al., 2006; Raikow et al., 2007a, b). Based on these studies, it is likely that brine treatment would be ineffective against dormant stages; however, the risk posed by dormant stages may be offset by high retention rates within tanks (i.e., dormant stages are not easily discharged from tanks)(Bailey et al., 
2006).

Finally, I acknowledge concerns with regards to the environmental impact of brine-treated ballast water being subsequently discharged at Great Lakes' ports. The relatively high concentration of brine used to treat residual ballast water (115\%) would be diluted to approximately $5.5 \%$ o by filling ballast tanks with additional Great Lakes ballast water prior to discharge. In contrast, full tanks treated to $45 \%$ would have to be discharged directly, since there likely will be no head space available to load additional fresh water into tanks for dilution purposes prior to discharge. In both scenarios, a further immediate dilution of $100 x$ is expected with discharge to a freshwater harbour (see Wells et al., 2010), resulting in brine concentrations of $\sim 55-450-\mathrm{mg} \mathrm{L}^{-1}\left(0.10 \% 0^{-0.81 \%)}\right)$. While any addition of brine to freshwater ecosystems is not desirable, the environmental impact of brine treatment would be limited by the fact that the estimated amount of brine needed to treat non-compliant tanks annually (approximately 500 tonnes, or 20 tanker trucks) is far exceeded by the amount of brine already entering the Great Lakes as run-off from winter road treatment. American states bordering the Great Lakes and the province of Ontario use about 5.2 million tonnes of road salt annually (Transportation Research Board, 1991; Environment Canada, 2001). Peak chloride concentrations in small streams draining urban Ontario watersheds can be as high as $5000-\mathrm{mg} \mathrm{L}^{-1}(9.1 \%)$, while the highest average discharge concentration discharged into Lake Ontario is $332-\mathrm{mg} \mathrm{L}^{-1}$ (Kaltenecker and Todd, 2007). Further, British Columbia has suggested that maximum chloride concentrations should not exceed $600-\mathrm{mg} \mathrm{L}^{-1}$ to protect sensitive aquatic species 
from acute toxicity (Kaltenecker and Todd, 2007). As a result, the environmental impact of brine ballast water treatment would appear minor in comparison to other sources entering the lakes. Furthermore, since it is virtually impossible to eradicate NIS after establishment, small discharges of brine are an obvious choice as the lesser of two evils.

If brine was approved as an alternate method for treatment of non-compliant tanks, brine stations could be set up at strategic points around the Great Lakes, especially in the St. Lawrence River or Seaway, to facilitate treatment and decrease application cost. Instead of having truck delivery of brine, as was the case in this study, vessels could be treated as they entered the Seaway from a common facility. A method to treat non-compliant ballast tanks may be required for the foreseeable future, as ballast water management systems utilizing filtration, de-oxygenation, biocides, and/or ultraviolet treatment are still in the developmental phase and will not be widely employed until approximately 2016 (Tsolaki and Diamadopoulos, 2010; Lloyd's Register, 2010). Brine treatment could also serve as a 'back-up' strategy for cases where ballast water management systems, once approved and implemented, break down during ship operations. 


\section{CHAPTER 3: GENERAL DISCUSSION}

The addition of brine appears to be a highly effective and operationally practical means for treatment of non-compliant freshwater ballast, which could be implemented immediately to reduce the risk of introduction of pelagic zooplankton. I observed that approximately 25 hours of exposure to $45 \%$ brine and approximately 5 hours exposure to $115 \%$ brine effectively exterminated freshwater zooplankton from ballast tanks having full, or residual, ballast on board, respectively. Further, vessel movement appears to be an essential component of successful brine treatment by facilitating mixing in ballast tanks. The movement of vessels in transit swirls ballast water inside ballast tanks and promotes mixing, as documented by videos taken while conducting the experiments. This swirling of water helps distribute brine to the far edges of tanks and helps achieve uniform distribution. Stationary vessels may encounter problems with brine mixing, as occurred during one of the residual ballast trials. Stationary vessels may be able to achieve adequate mixing by adjusting the ships' trim and/or list through shifting of cargo or ballast water.

While brine treatment was very effective against pelagic zooplankton in all of the trials conducted, additional studies with phytoplankton, bacteria, and viruses should be conducted to confirm efficacy for a wider array of ballast-mediated taxa. A microcosm experiment conducted by Greenwald and Hurlbert (1993) found that total zooplankton abundance decreased with salinity. This is consistent with the experiments conducted in Chapter 2. $\mathrm{NaCl}$ brine treatment may also be effective on freshwater phytoplankton as a study conducted by Redden and 
Rukminasari (2008) found that an increase in salinity reduces phytoplankton abundance. However, high salinity treatment against saltwater phytoplankton may not be effective (Greenwald and Hurlbert, 1993).

In the field experiments conducted here, brine was delivered by tanker truck. This method of delivery may not be effective on a larger scale due to many factors that could delay or prevent brine trucks from reaching their destination. During the field experiments, there were incidents where the brine truck broke down en route and/or became stuck in traffic. To solve this problem, it may be possible to set up a number of brine stations at major Great Lakes ports or at strategic locations, such as the Welland Canal. In doing so, vessels needing brine treatment can receive it immediately, increasing the utility of brine treatment as a back-up method by reducing costs of delivery and time. Jenkins (2007) estimated that cost of treatment, which includes brine, transportation, and labour, could range from $\$ 5,200$ to $\$ 7,200$. The amount of brine needed to treat ballast tanks depends on the salinity of the ballast water in those tanks. The higher the salinity in the ballast tanks, the less brine needed to treat the water. In the experiments described here, no more than $20,000 \mathrm{~L}$ of brine were needed per tank treatment.

One problem that ballast-on-board vessels may encounter is an inability to receive the extra volume required to treat fully loaded tanks with brine. It may be possible to accommodate the addition of brine by dividing fully loaded tanks into multiple empty tanks so that there is room to compensate for the additional volume. no-ballast-on-board (NOBOB) vessels will not have this problem 
because treatment would be applied while the tanks are nearly empty of ballast water.

The environmental impacts of brine treatment of non-compliant vessels will be relatively insignificant in comparison to other brine applications around the Great Lakes. The amount of road salt and brine used annually for de-icing roads around the Great Lakes region during winter far exceeds the amount of brine needed to treat non-compliant vessels annually. For NOBOB vessels, the treated residuals will be diluted to approximately $5 \%$ and thus no acute toxicity effects are expected. In contrast, fully ballasted tanks treated with brine to a salinity of approximately $45 \%$ will be discharged directly without dilution due to the fact that there is no room in the tanks for the addition of freshwater. While acute toxicity effects are possible, dilution of approximately 100 times is expected when treated ballast water is discharged into the Great Lakes, bringing the brine concentration to $55-450 \mathrm{mg} \mathrm{L}^{-1}(0.1 \% 0-0.81 \%)$. This range is well below the $5,000 \mathrm{mg} / \mathrm{L}(9.1 \%$ o $)$ chloride discharge limit for Ontario (Kaltenecker and Todd, 2007). Each of the eight Great Lakes states have their own maximum permissible chloride discharge limit (Table 5). While the addition of brine into freshwater ecosystems is not ideal, it is less harmful than the possible alternative of new successful invasions.

The International Maritime Organization (IMO) has proposed ballast water discharge standards under the Ballast Water Management Convention that, once ratified, will require all vessels operating in international waters to treat ballast water with approved treatment systems (IMO, 2004). With an expected implementation deadline of 2016 , there are at least 41 ballast water treatment 
systems that are at various stages of development and approval (Lloyd's Register, 2010), including systems which make use of physical, mechanical and/or chemical treatment processes. All of the treatment methods have their own advantages and disadvantages, each suited to a particular set of operating conditions.

Filtration systems, usually used in combination with other treatment processes, remove organisms and particles above a certain size by forcing water through a filter that will retain target organisms. This method is ideal because the addition of chemicals to ballast water is not required (Kazumi, 2007). The filtered organisms can be stored and disposed of or discharged back into the source environment. A disadvantage to this method is that the flux of water through filters can be immensely reduced as organisms are deposited onto the filter surface (Boylston, 1996), requiring constant cleaning to ensure good water flow through filters.

Treatment using biocides has the advantage of ease of application. Concentrated solid or liquid chemicals such as sodium chloride or hydrogen peroxide may be added directly to ballast tanks or intake lines. Effective biocide concentrations may be maintained by automatic feed systems. One of the disadvantages of this method, however, is the potential for negative environmental impacts due to spills or incomplete neutralization before ballast water is discharged into recipient aquatic ecosystems (Boylston, 1996; Kazumi, 2007). A group of experts on the scientific aspects of marine environmental protection (GESAMP Ballast Water Working Group) was established specifically 
to review systems utilizing chemicals or other active substances during the IMO approval process in order to minimize associated environmental impacts.

Heat treatment using waste heat from a ship's propulsion system is ideal for some situations in which sufficient heat can be generated to kill organisms as no chemical products are utilized. For example, temperatures of $38^{\circ} \mathrm{C}$ for over 30 hours was enough to kill all zooplankton and the majority of phytoplankton in shipboard trials conducted by Rigby et al. (1999). Heat treatment, however, may not be practical for short voyages or large volumes of ballast water since there may be insufficient time or energy to heat the ballast water to the desired temperature (Boylston, 1996).

While there are many more treatment methods, there will inevitably be situations where a system has malfunctioned or broken down. While $\mathrm{NaCl}$ brine treatment is not practical for use as a primary method of ballast treatment, it will remain a cost-effective and easy-to-apply back-up treatment method as vessels transition to the use of technological treatment systems in the coming years. Ballast water may carry a diverse community of aquatic taxa and is an important vector requiring careful management to reduce future biological invasions. The brine treatment method outlined in this thesis is a promising new tool for ballast water management that can be used to prevent further zooplankton invasions in the Great Lakes. 
Table 1. IMO's D-2 standard for maximum density of organisms discharged after ballast water treatment (IMO, 2010). (cfu = colony forming unit).

\begin{tabular}{|c|c|}
\hline Organism size or Indicator Microbe & $\begin{array}{c}\text { Maximum Permissible Density in } \\
\text { Treated Ballast effluent }\end{array}$ \\
\hline $\begin{array}{c}\text { Organisms } \geq 50 \mu m \text { in minimum } \\
\text { dimension }\end{array}$ & $<10$ viable organisms $\mathrm{m}^{-3}$ \\
\hline $\begin{array}{c}\text { Organisms }<50 \mu \mathrm{m} \geq 10 \mu \mathrm{m} \text { in minimum } \\
\text { dimension }\end{array}$ & $<10$ viable organisms $\mathrm{mL}^{-1}$ \\
\hline $\begin{array}{l}\text { Toxicogenic Vibrio cholera } \\
\text { (01 and O139) }\end{array}$ & $\begin{array}{c}<1 \mathrm{cfu} 100 \mathrm{~mL}^{-1} \text { or } \\
<1 \mathrm{cfu} \mathrm{g}^{-1} \text { zooplankton samples (wet } \\
\text { weight) }\end{array}$ \\
\hline Escherichia coli & $<250 \mathrm{cfu} 100 \mathrm{~mL}^{-1}$ \\
\hline Intestinal enterococci & $<100 \mathrm{cfu} 100 \mathrm{~mL}^{-1}$ \\
\hline
\end{tabular}


Table 2. Experiment locations, date, and amount of brine applied. The initial concentration of brine was $230 \%$ and was manufactured by Road Maintenance Equipment \& Services Inc. in Cobourg, ON. Location refers to initial port where brine was applied, and the destination port, respectively, unless the ship was stationary in port.

\begin{tabular}{|c|c|c|c|c|}
\hline Experiment & Date & Location & $\begin{array}{l}\text { Target/Final } \\
\text { salinity (\%o) }\end{array}$ & $\begin{array}{c}\text { Volume of } \\
\text { brine } \\
\text { applied }\end{array}$ \\
\hline BOB 1 & $\begin{array}{l}\text { June } 16,2009 \text { to } \\
\text { June } 20,2009\end{array}$ & $\begin{array}{c}\text { Toronto, ON to } \\
\text { Thunder Bay, } \\
\text { ON }\end{array}$ & $45 / 50$ & $\sim 20,000 \mathrm{~L}$ \\
\hline BOB 2 & $\begin{array}{l}\text { Sept. 30, } 2009 \\
\text { to Oct. 2, } 2009\end{array}$ & $\begin{array}{c}\text { Toronto, ON to } \\
\text { Thunder Bay, } \\
\text { ON }\end{array}$ & $45 / 38$ & $24,445 \mathrm{~L}$ \\
\hline BOB 3 & $\begin{array}{l}\text { Oct. } 22,2009 \text { to } \\
\text { Oct. } 24,2009\end{array}$ & $\begin{array}{l}\text { Toronto, ON to } \\
\text { Thunder Bay, } \\
\text { ON }\end{array}$ & $45 / 35$ & $20,000 \mathrm{~L}$ \\
\hline NOBOB 1 & Nov. 22, 2008 & Sarnia, ON & $115 / 125$ & $\sim 10,000 \mathrm{~L}$ \\
\hline NOBOB 2 & May 27, 2009 & Sarnia, ON & $115 / 117$ & $\sim 10,000 \mathrm{~L}$ \\
\hline NOBOB 3 & Dec. 16, 2009 & Sarnia, ON & $115 / 158$ & $\sim 10,000 \mathrm{~L}$ \\
\hline
\end{tabular}


Table 3. Measurements of temperature, conductivity, dissolved oxygen, and $\mathrm{pH}$ in control and treatment tanks for the three ballast-on-board shipboard trials.

\begin{tabular}{|c|c|c|c|c|c|}
\hline \multirow{2}{*}{$\begin{array}{c}\begin{array}{c}\text { 1st ballast-on-board } \\
\text { vessel }\end{array} \\
\text { Parameters }\end{array}$} & & & & & \\
\hline & \multicolumn{5}{|c|}{ Control } \\
\hline Time (Hours) & 0 & 1 & 10 & 25 & 44 \\
\hline Temperature $\left({ }^{\circ} \mathrm{C}\right)$ & 13.8 & 13.8 & 13.8 & 14.7 & 15.5 \\
\hline Conductivity $\left(\mathrm{mS} \mathrm{cm}^{-3}\right)$ & 725 & 731 & 733 & 752 & 768 \\
\hline Oxygen $\left(\mathrm{mg} \mathrm{L}^{-1}\right)$ & 10.3 & 9.8 & 9.8 & 9.7 & 8.8 \\
\hline $\mathrm{pH}$ & 7.7 & 7.5 & 8 & 7.9 & 7.9 \\
\hline \multicolumn{6}{|l|}{$\begin{array}{l}\text { 2nd ballast-on-board } \\
\text { vessel }\end{array}$} \\
\hline Parameters & \multicolumn{5}{|c|}{ Control } \\
\hline Time (Hours) & 0 & 1 & 10 & 25 & 44 \\
\hline Temperature $\left({ }^{\circ} \mathrm{C}\right)$ & 17.3 & 17 & 16.6 & 16.4 & 16 \\
\hline Conductivity $\left(\mathrm{mS} \mathrm{cm}^{-3}\right)$ & 0.4 & 0.4 & 0.4 & 0.4 & 0.4 \\
\hline Oxygen $\left(\mathrm{mg} \mathrm{L}^{-1}\right)$ & 6.8 & 7.3 & 7.2 & 6.8 & 7 \\
\hline $\mathrm{pH}$ & 7.1 & 7.4 & 7.9 & 7.8 & 7.8 \\
\hline \multicolumn{6}{|l|}{$\begin{array}{c}\text { 3rd ballast-on-board } \\
\text { vessel }\end{array}$} \\
\hline Parameters & \multicolumn{5}{|c|}{ Control } \\
\hline Time (Hours) & 0 & 1 & 10 & 25 & 44 \\
\hline Temperature $\left({ }^{\circ} \mathrm{C}\right)$ & 9 & 8.7 & 8.7 & 9 & 8.8 \\
\hline Conductivity $\left(\mathrm{mS} \mathrm{cm}^{-3}\right)$ & 0.5 & 0.5 & 0.6 & 0.5 & 0.5 \\
\hline Oxygen $\left(\mathrm{mg} \mathrm{L}^{-1}\right)$ & 11.8 & 12.2 & 13 & 12.9 & 11.5 \\
\hline $\mathrm{pH}$ & 7.7 & 7.6 & 7.6 & 7.4 & 7.5 \\
\hline \multicolumn{6}{|l|}{$\begin{array}{c}\text { 1st ballast-on-board } \\
\text { vessel }\end{array}$} \\
\hline Parameters & \multicolumn{5}{|c|}{ Treatment } \\
\hline Time (Hours) & 0 & 1 & 10 & 25 & 44 \\
\hline Temperature $\left({ }^{\circ} \mathrm{C}\right)$ & 14.3 & 14.4 & 14.5 & 15.4 & 16.5 \\
\hline Conductivity $\left(\mathrm{mS} \mathrm{cm}^{-3}\right)$ & 914 & 88565 & 83815 & 84230 & 84196 \\
\hline Oxygen $\left(\mathrm{mg} \mathrm{L}^{-1}\right)$ & 10.5 & 7.8 & 8 & 7.8 & 7.6 \\
\hline $\mathrm{pH}$ & 7.8 & 7.6 & 7.6 & 7.6 & 7.6 \\
\hline \multicolumn{6}{|l|}{$\begin{array}{l}\text { 2nd ballast-on-board } \\
\text { vessel }\end{array}$} \\
\hline Parameters & \multicolumn{5}{|c|}{ Treatment } \\
\hline Time (Hours) & 0 & 1 & 10 & 25 & 44 \\
\hline Temperature $\left({ }^{\circ} \mathrm{C}\right)$ & 17.1 & 16.4 & 16.3 & 16.3 & 16.3 \\
\hline Conductivity $\left(\mathrm{mS} \mathrm{cm}^{-3}\right)$ & 0.4 & 77 & 68 & 68 & 68 \\
\hline Oxygen $\left(\mathrm{mg} \mathrm{L}^{-1}\right)$ & 7.5 & 5.2 & 5.9 & 5.8 & 6.1 \\
\hline
\end{tabular}




\begin{tabular}{|c|c|c|c|c|c|}
\hline $\mathrm{pH}$ & 7.3 & 6.9 & 7 & 7 & 7 \\
\hline $\begin{array}{c}\text { 3rd ballast-on-board } \\
\text { vessel }\end{array}$ & \multicolumn{5}{|c|}{ Treatment } \\
\hline $\begin{array}{c}\text { Parameters } \\
\text { Time (Hours) }\end{array}$ & $\mathbf{0}$ & $\mathbf{1}$ & $\mathbf{1 0}$ & $\mathbf{2 5}$ & $\mathbf{4 4}$ \\
\hline Temperature $\left({ }^{\circ} \mathrm{C}\right)$ & 9 & 8 & 8.2 & 8.7 & 8.9 \\
\hline Conductivity $\left(\mathrm{mS} \mathrm{cm}^{-3}\right)$ & 1.2 & 76 & 59 & 58 & 56 \\
\hline Oxygen $\left(\mathrm{mg} \mathrm{L}^{-1}\right)$ & 12.4 & 10 & 11.9 & & \\
\hline $\mathrm{pH}$ & 7.8 & 7.1 & 7.1 & & \\
\hline
\end{tabular}


Table 4. ANOVA with repeated measures demonstrating the effects of brine on live zooplankton abundance. Significance levels for F-values: * $(p<0.05)$, ${ }^{* *}(0.1>p>0.05)$.

\begin{tabular}{|l|l|l|l|}
\hline & \multicolumn{3}{|c|}{ ANOVA effects } \\
\hline & \multicolumn{3}{|c|}{ F values (df) } \\
\hline & Treatment & Time & Treatment ${ }^{\star}$ Time \\
\hline Ballast-on-board experiment & $335.02^{*}(1,2)$ & $6.69^{*}(4,8)$ & $3.57^{* *}(4,8)$ \\
\hline No-ballast-on-board experiment & $168.05^{*}(1.2)$ & $9.93^{*}(3,6)$ & $20.72^{*}(3,6)$ \\
\hline
\end{tabular}


Table 5. Maximum permissible chloride values permitted in ballast water discharge by each of the eight Great Lakes states and Ontario (Gregory and Sindt, 2008; Kaltenecker and Todd, 2007; PWEA 2010; Stollenwerk, 2009).

\begin{tabular}{|c|c|c|}
\hline State and Province & Chloride (mg/L) & Salinity (\%) \\
\hline Illinois & 500 & 0.91 \\
\hline Indiana & N/A $/ A$ \\
\hline Michigan & 250 & 0.45 \\
\hline Minnesota & N/A & N/A \\
\hline New York & N/A $/ A$ \\
\hline Ohio & N/A & N/A \\
\hline Pennsylvania & 250 & 0.45 \\
\hline Wisconsin & 1514 & 2.70 \\
\hline Ontario & 5000 & 9.10 \\
\hline
\end{tabular}


Figure 1: Changes in salinity $( \pm S E)$ following addition of brine into treatment tank for the three ballasted vessels.

\section{- Control Tank - Treatment Tank}

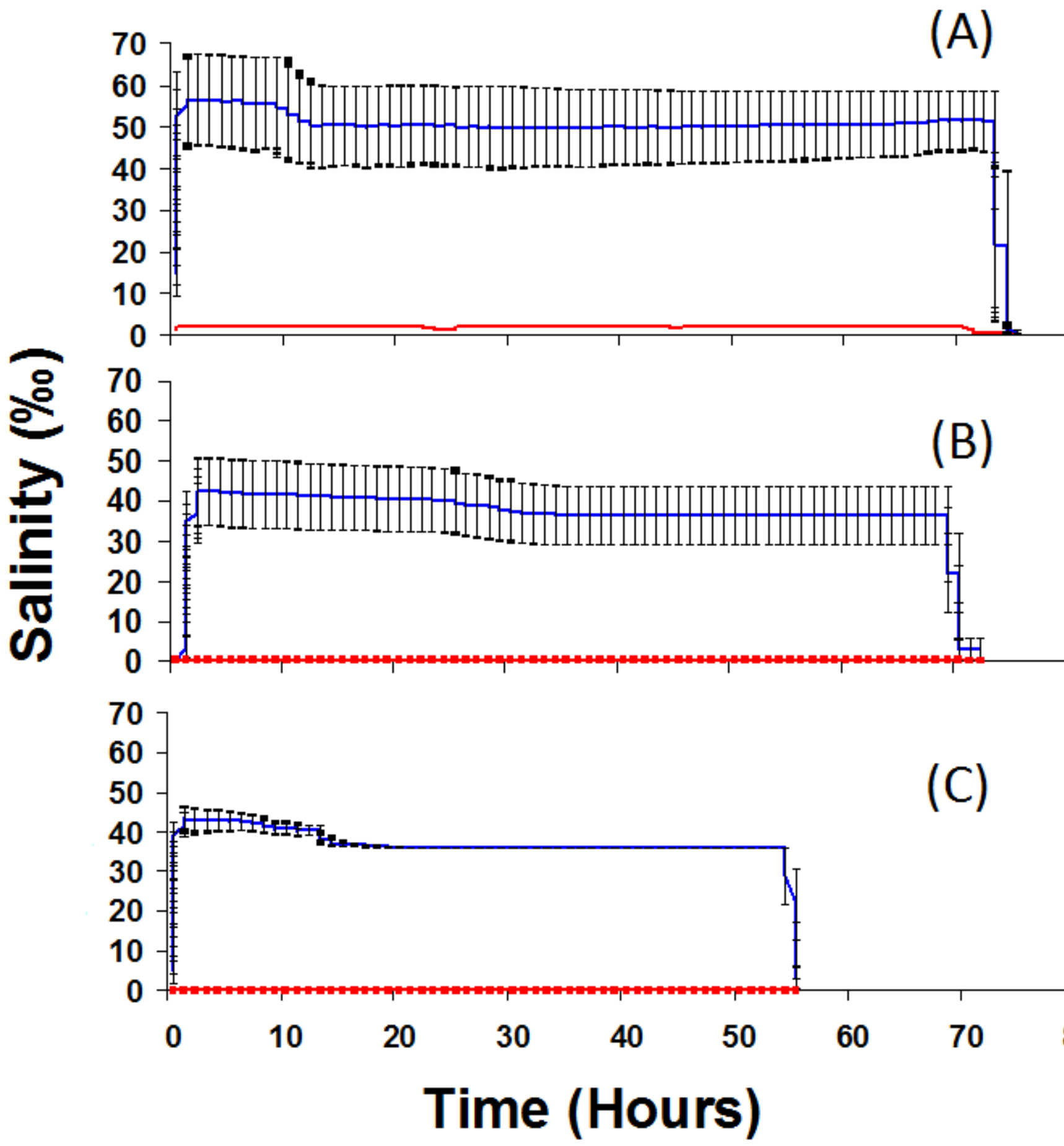


Figure 2: Changes in (A) mean $( \pm S E)$ live abundance of zooplankton and (B) mean $( \pm S E)$ proportion of total viable zooplankton in control and treatment tanks for ballasted tank experiments following brine treatment.

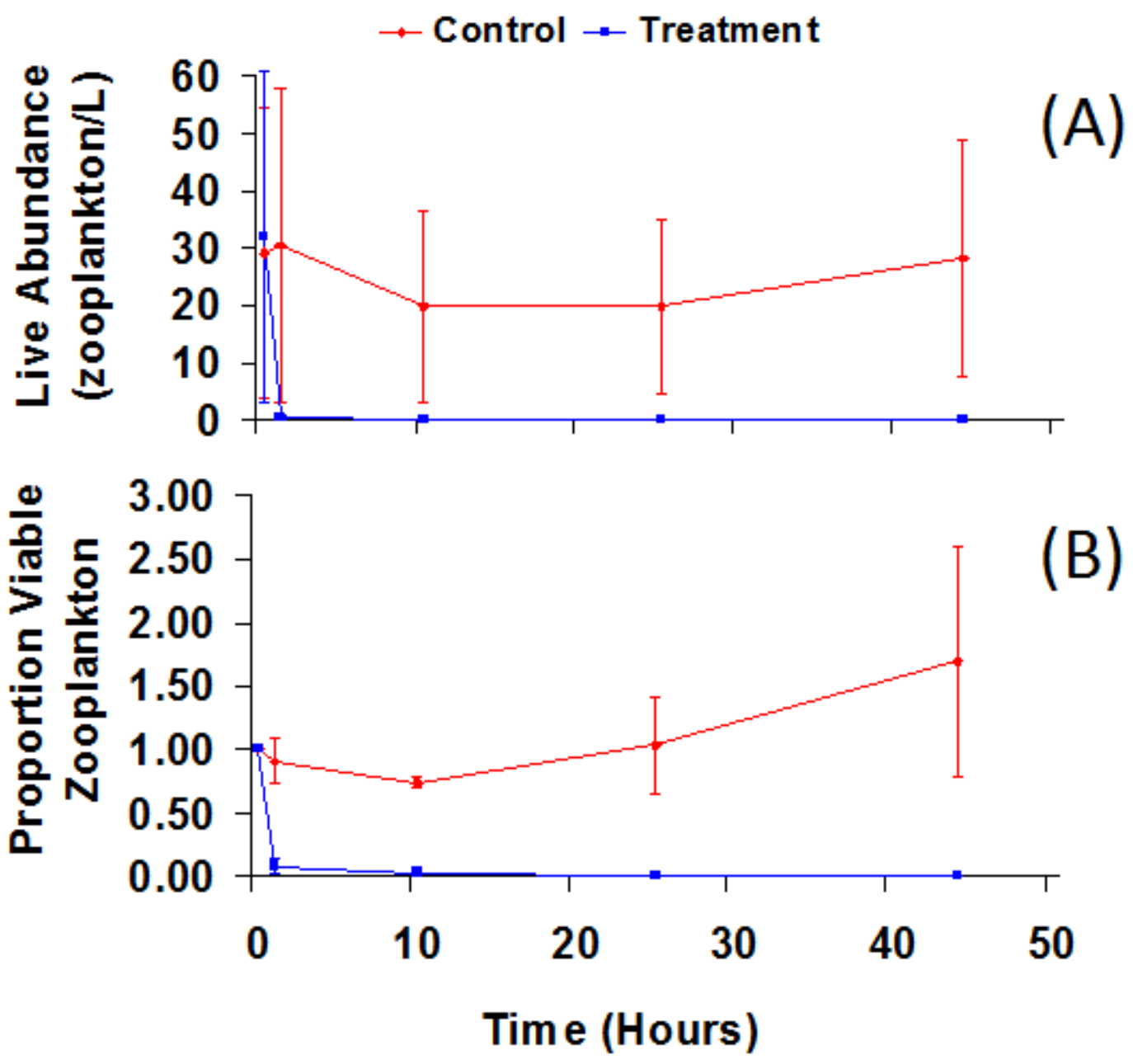


Figure 3: Changes in mean $( \pm S E)$ salinity over time in control and treatment tanks in ballast residuals experiments.

$\rightarrow$ Control $\rightarrow-$ Treatment

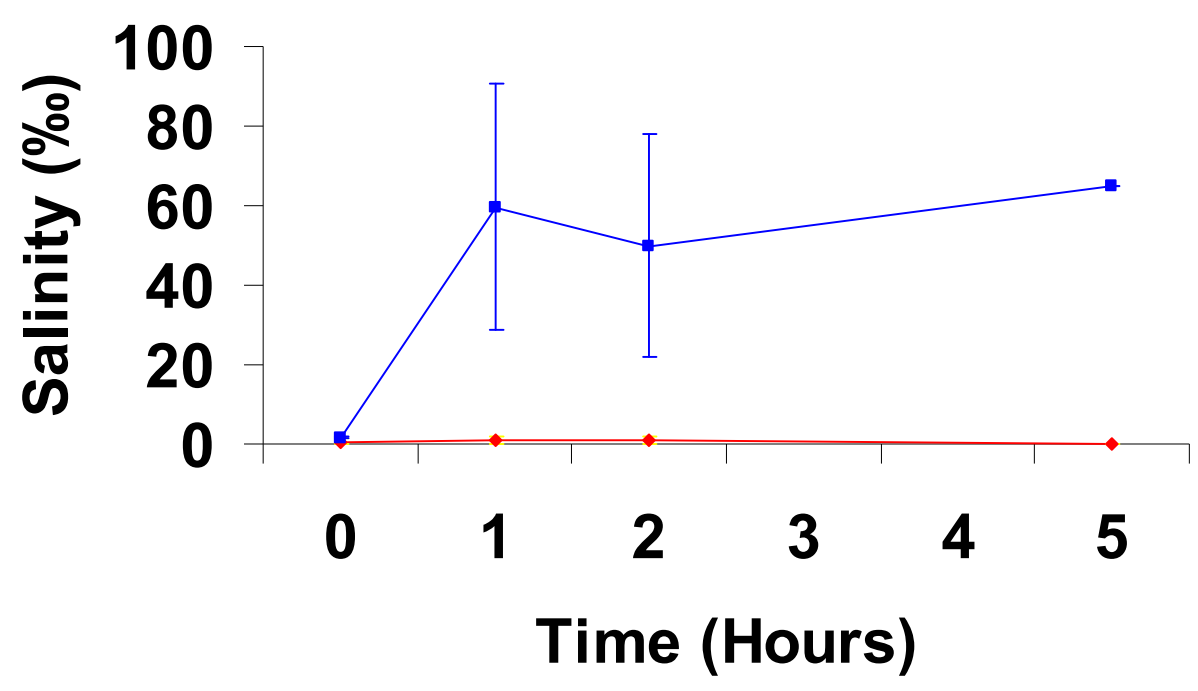


Figure 4: Changes in (A) mean $( \pm S E)$ live abundance of zooplankton and (B) mean $( \pm S E)$ proportion of total viable zooplankton incontrol and treatment tanks for ballast residuals experiments following brine application.
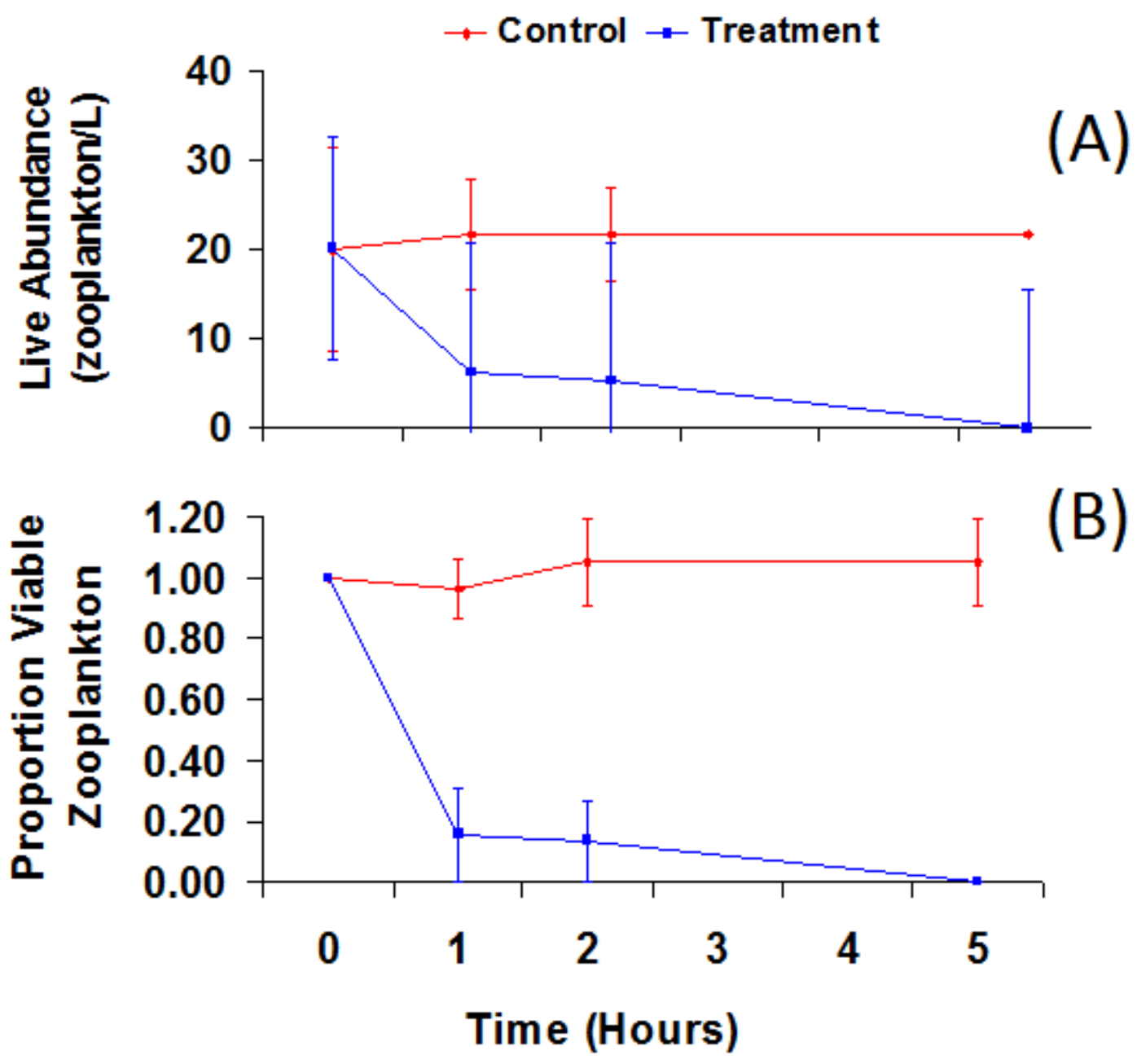


\section{References}

Bailey, S.A., Deneau, M.G., Jean, L., Wiley, C.J., Leung, B., Maclsaac, H.J., 2010. Evaluating efficacy of an environmental policy to prevent biological invasions. Environmental Science and Technology. In revision.

Bailey, S.A., Duggan, I.C., van Overdijk, C.D.A., Johengen, T.H., Reid, D.F., Maclsaac, H.J., 2004. Salinity tolerance of diapausing eggs of freshwater zooplankton. Freshwater Biology 49: 286-295.

Bailey, S.A., Nandakumar, K., Duggan, I.C., van Overdijk, C.D.A., Johengen, T.H., Reid, D.F., Maclsaac, H.J., 2005. In situ hatching of invertebrate diapausing eggs from ships' ballast sediment. Diversity and Distributions 11, 453-460.

Bailey, S.A., Nandakumar, K., Maclsaac, H.J., 2006. Does saltwater flushing reduce viability of diapausing eggs in ship ballast sediment? Diversity and Distributions 12, 328-335.

Boylston, J.W. 1996. Ballast water management for the control of non-indigenous species. SNAME Transactions 104: 391-417.

Bradie, J.N., Bailey, S.A., van der Velde, G., Maclsaac, H.J. 2010. Brine-induced mortality of non-indigenous species in ballast water. Marine Environmental Research 70: 395-401.

Bright, C. 1999. Invasive species: pathogen of globalization. Foreign Policy. 5064.

Briski, E., Cristescu, M.E., Bailey, S.A., Maclsaac, H.J., 2010. Efficacy of saltwater flushing' in protecting the Great Lakes from biological invasions by 
invertebrate eggs in ships. Freshwater Biology. in press: doi:10.1111/j.13652427.2010.02449.x

California Environmental Protection Agency. 2002. Evaluation of ballast water treatment technology for control of non-indigenous aquatic organisms. Retrieved from:

http://www.calepa.ca.gov/publications/Reports/Mandated/2002/BallastWater .pdf

Carlton, J. T. 1999. The scale and ecological consequences of biological invasions in the world's oceans. In: Invasive Species and Biodiversity Management pp. 195-212. Ed. by O. T. Sandlund, P. J. Schei, and P. Viken. Kluwer Academic Publishers, Dordrecht, The Netherlands.

Choi, K., Kimmerer, W., Smith, G., Ruiz, G.M., Lion, K. 2005. Post-exchange zooplankton in ballast water of ships entering the San Francisco estuary. Journal of Plankton Research 27: 707-714.

Colautti, R.I. and Maclsaac, H.J. 2004. A neutral terminology to define 'invasive' species. Diversity and Distributions 10: 135-141.

Colautti, R. I., Bailey, S. A., van Overdijk, C. D. A., Amundsen, K., Maclsaac, H. J. 2006a. Characterized and projected costs of nonindigenous species in Canada. Biological Invasions 8: 45-49.

Colautti, R.I., Grigorovich, I.A., Maclsaac, H.J. 2006b. Propagule pressure: null model for biological invasions. Biological Invasions 8: 1023-1037.

Cordell, J.R., Tear, L.M., Bollens, S.M. 2010. Modelling physico-chemical factors 
affecting occurrences of a non-indigenous planktonic copepod in northeast Pacific estuaries. Biological Invasions 12: 1427-1445.

Drake, J.M., Lodge, D.M. 2004. Global hot spots of biological invasions: evaluating options for ballast-water management. Proceedings of the royal society $271: 575-580$.

Dodgshun, T.J., Taylor, M.D., Forrest, B.M. 2007. Human-mediated pathways of spread for non-indigenous marine species in New Zealand. New Zealand Department of Conservation Series 226: 1-44.

Duggan, I.C., Bailey, S.A., Colautti, R.I., Gray, D.K., Makarewicz, C., Maclsaac, H.J. 2003. Biological invasions in Lake Ontario: past, present and future. State of Lake Ontario pp. 541-558.

Ellis, S., Maclsaac, H.J. 2008. Salinity tolerance of Great Lakes' invaders. Freshwater Biology 54: 77-89.

Environment Canada, 2001. Canadian environmental protection act, 1999, priority substances list assessment report: road salts. Retrieved from: http://www.ec.gc.ca/substances/ese/eng/psap/final/roadsalts.cfm

Foster, S.E., Sprules, W.G., 2010. Effects of Bythotrephes on the trophic position of native macroinvertebrates. Canadian Journal of Fisheries and Aquatic Sciences 67: 58-69.

Gavand, M.R., McClintock, J.B., Amsler, C.D., Peters, R.W., Angus, R.A. 2007. Effects of sonication and advanced chemical oxidants on the unicellular green alga Dunaliella tertiolecta and cysts, larvae and adults of brine shrimp Artemia salina: a prospective treatment to eradicate invasive organisms 
from ballast water. Marine Pollution Bulletin 54: 1777-1788.

GLSBWWG [Great Lakes Seaway Ballast Water Working Group], 2009. 2008 Summary of Great Lakes seaway ballast water working group. Retrieved from: http://www.greatlakes-seaway.com/en/pdf/2008_BW_Rpt_EN.pdf

Gray, D.K. 2007. Ballast water treatments to limit the transfer of nonindigenous species between freshwater ports. Master of Science thesis. University of Windsor.

Gray, D.K., Duggan, I.C., Maclsaac, H.J., 2006. Can sodium hypochlorite reduce the risk of species introductions from diapausing invertebrate eggs in nonballasted ships? Marine Pollution Bulletin 52: 689-695.

Gray, D.K., Johengen, T.H., Reid, D.F., Maclsaac, H.J., 2007. Efficacy of openocean ballast water exchange as a means of preventing invertebrate invasions between freshwater ports. Limnology and Oceanography 52: 2386-2397.

Greenwald, G.M., Hurlbert, S.H. 1993. Microcosm analysis of salinity effects on coastal lagoon plankton assemblages. Hydrobiologia 267: 307-335.

Government of Canada. 2006. Ballast water control and management regulations. Canada Gazette 140 (13), SOR/2006-129

Hovius, J.T., Beisner, B.E. 2007. Indirect food web effects of Bythotrephes invasion: responses by the rotifer Conochilus in Harp Lake, Canada. Biological Invasions 9: 233-243.

Hovius, J.T., Beisner, B.E., McCann, K.S., Yan, N.D. 2007. Indirect food web effects of Bythotrephes invasion: response by the rotifer Conochilus in Harp 
Lake, Canada. Biological Invasions 9: 233-243.

IMO [International Maritime Organization]. 2004. International convention for the control and management of ships' ballast water and sediments, adopted 13 February 2004. Retrieved from: www.imo.org

IMO. 2010. International convention for the control and management of ships' ballast water and sediments (BWM). Retrieves from: http://www.imo.org/About/Conventions/ListOfConventions/Pages/Internation al-Convention-for-the-Control-and-Management-of-Ships\%27-Ballast-Waterand-Sediments-\%28BWM\%29.aspx

Jenkins, P.T., 2007. Brine as a treatment solution for the control of aquatic nuisance species introductions into the Great Lakes by NOBOB vessels: a feasibility study prepared for Transport Canada - marine safety. Philip T. Jenkins \& Associates Ltd, pp. 1-38.

Jones, L.A., Ricciardi, A. 2005. Influence of physicochemical factors on the distribution and biomass of invasive mussels (Dreissena polymorpha and Dreissena bugensis) in the St. Lawrence River. Canadian Journal Of Fisheries and Aquatic Sciences 62: 1953-1962.

Kaltenecker, G., Todd, A., 2007. Chloride concentrations in Ontario's rivers and streams: a summary of water quality monitoring results. Ontario Ministry of the Environment. Retrieved from: http://www.ogra.org/lib/db2file.asp?fileid=18135

Karatayev, A.Y., Burlakova, L.E., Padilla, D.K., Mastitsky, S.E. 2009. Invaders are not a random selection of species. Biological Invasions 11: 2009-2019. 
Kazumi, J. 2007. Ballast water treatment technologies and their application for vessels entering the Great Lakes via the St. Lawrence Seaway, pp. 1-20. Kelly, D.W., Lamberti, G.A., Maclsaac, H.J., 2009. The Laurentian Great Lakes as a case study of biological invasion. In: Keller, R.P, Lodge, D.M., Lewis, M.A., Shogren, J.F. (Eds.), Bioeconomics of Invasive Species: Integrating Ecology, Economics, Policy, and Management. Oxford University Press, New York, NY, USA, pp. 205-225.

Kolar, C. S., D. M. Lodge. 2001. Progress in invasion biology: predicting invaders. Trends in Ecology and Evolution 19:199-204.

Leung, B., Mandrak, N.E. 2007. The risk of establishment of aquatic invasive species: joining invasibility and propagule pressure. Proceedings of the Royal Society B. 274: 2603-2609.

Lloyd's Register, 2010. Ballast water treatment technology current status February 2010. Retrieved from: http://www.Ir.org/Images/BWT0210_tcm155175072.pdf

Lockwood, J.L., Cassey, P., Blackburn, T., 2005. The role of propagule pressure in explaining species invasions. Trends Ecology and Evolution 20: 223-228. Lockwood, J.L., Hoopes, M.F., Marchetti, M.P. 2007. Invasion Ecology. Blackwell Publishing.

Machida, R.J., Hashiguchi, Y., Mishida, M., Mishida, S. 2009. Zooplankton diversity analysis through single-gene sequencing of a community sample. BioMed Central Genomics 10: 438-445.

McCollin, T., Shanks, A.M., Dunn, J. 2008. Changes in zooplankton abundance 
and diversity after ballast water exchange in regional seas. Marine Pollution Bulletin 56: 834-844.

McKinney, M.L., Lockwood, J.J. 1999. Biotic homogenization: a few winners replacing many losers in the next mass extinction. Trends in Ecology and Evolution 14: 450-453.

NOAA. 2006. Great Lakes aquatic nonindigenous species list. National Center for research on aquatic invasive species. Retrieved from: http://www.glerl.noaa.gov/res/Programs/ncrais/great_lakes_list.html Olden, J.D., Kennard, M.J., Pusey, B.J. 2008. Species invasions and the changing biogeography of Australian freshwater fishes. Global Ecology and Biogeography 17: 25-37.

Piola, R.F, Dafforn, K.A., Johnston, E.L. 2009. The influence of antifouling practices on marine invasions. Biofouling 25: 633-644.

PWEA. 2010. TDS proposed discharge limits. Retrieved from: http://www.pwea.org/news-and-info/article/?article_id=87

Rahel, F.J. 2002. Homogenization of freshwater faunas. Annual Review of Ecology and Systematics 33: 291-315.

Raikow, D.F., Reid, D.F., Blatchley, E.R, Jacobs, G., Landrum, P.F., 2007a. Effects of proposed physical ballast tank treatments on aquatic invertebrate resting eggs. Environmental Toxicology and Chemistry 26: 717-725.

Raikow, D.F., Reid, D.F. and Landrum, P.F. 2007b. Aquatic invertebrate resting egg sensitivity to glutaraldehyde and sodium hypochlorite. Environment Toxicology Chemistry 26: 1770-1773. 
Redden, A.M., Rukminasari, N. 2008. Effects of increases in salinity on phytoplankton in the Broadwater of the Myall Lakes, NSW, Australia. Hydrobiologia 608: 87-97.

Ricciardi, A. 2001. Facilitative interactions among aquatic invaders: is an "invasional meltdown" occurring in the Great Lakes? Canadian Journal of Fisheries Aquatic. Sciences 58: 2513-2525.

Ricciardi, A. 2006. Are modern biological invasions an unprecedented form of global change? Conservation Biology 21: 329-336.

Ricciardi, A. 2006. Patterns of invasion in the Laurentian Great Lakes in relation to changes in vector activity. Diversity and Distributions $12: 425-433$.

Rigby, G.R., G.M. Hallegraeff and C. Sutton, 1999. Novel ballast water heating technique offers cost effective treatment to reduce the risk of global transport of harmful marine organisms. Marine Ecology Progress Series. 191: $289-293$.

Ruiz, G.M., Carlton, J.T., Grosholz, E.D., Hines, A.H. 1997. Global invasions of marine and estuaries habitats by non-indigenous species: mechanics, extent, and consequences. American Zoologist 37: 621-632.

Ruiz, G., Reid, D.F., 2007. Current State of Understanding about the Effectiveness of Ballast Water Exchange (BWE) in Reducing Aquatic Nonindigenous Species (ANS) Introductions to the Great Lakes Basin and Chesapeake Bay, USA: Synthesis and Analysis of Existing Information. National Oceanic and Atmospheric Administration, Technical Memorandum GLERL-142, Great Lakes Environmental Research Lab, Ann Arbor, MI, 
U.S.A., pp. 127.

Sagata, K., Lester, P. 2008. Behavioural plasticity associated with propagule size, resources, and the invasion success of the Argentine ant Linepithema humile. Journal of Applied Ecology 46: 19-27.

Santagata, S., Gasiunaite, Z.R., Verling, E., Cordell, J.R., Eason, K., Cohen, J.S., Bacela, K., Quilez-Badia, G., Johengen, T.H., Reid, D.F., Ruiz, G.M., 2008. Effect of osmotic shock as a management strategy to reduce transfers of nonindigenous species among low-salinity ports by ships. Aquatic Invasions 3: 61-76.

SLSDC [Saint Lawrence Seaway Development Corporation]. 2008. Seaway Regulations and Rules: Periodic Update, Various Categories. Code of Federal Regulations 33-CFR Part 401.

Santagata, S., Bacela, K., Reid, D.F., Mclean, K., Cohen, J.S., Cordell, J.R., Brown, C., Johengen, T.H., Ruiz, G.M., 2009. Eradicating ballast-tank organisms with sodium chloride treatments. Environmental Toxicology and Chemistry 28: 346-353.

Schulz, K. L., Yurista, P.M. 1999. Implications of an invertebrate predator's (Bythotrephes cederstroemi) a typical effects on a pelagic zooplankton community. Hydrobiologia 380: 179-193.

Simberloff, D. 2009. The role of propagule pressure in biological invasions. Annual Reviews of Ecology, Evolution, and Systematics 40: 81-102. Sprules, W.G, Riessen, H.P., Jin, E.H. 1990. Dynamics of the Bythotrephes invasion of the St. Lawrence Great Lakes. Journal of Great Lakes Research 
16: $346-351$.

Stollenwerk, J. 2009. Introductions and comments from the States. Minnesota pollution Control Agency. Retrieved from: http://www.greatlakesseaway.com/en/pdf/Stollenwerk_Introductions_and_Comments_from_State s.pdf

Strecker, A.L., and Arnott, S.E. 2005. Impact of Bythotrephes invasion on zooplankton communities in acid-damaged and recovered lakes on the Boreal Shield. Canadian Journal of Fisheries and Aquatic Sciences 62: $2450-2462$.

Sylvester, F., Maclsaac, H.J. 2010. Is vessel hull fouling an invasion threat to the Great Lakes. Diversity and Distributions 16: 132-143.

Tamurri, M.N., Wasson, K., Matsuda, M. 2002. Ballast water deoxygenation can prevent aquatic introductions while reducing ship corrosion. Biological Conservation 103: 331-341.

Tang, K.W, Freund, C.S., Schweitzer, C.L., 2006. Occurrence of copepod carcasses in the lower Chesapeake Bay and their decomposition by ambient microbes. Estuarine, Coastal and Shelf Science 68: 499-508.

Transport Canada. 2010. Ballast water management. Retrieved from: http://www.tc.gc.ca/eng/marinesafety/oep-environment-ballastwatermanagement-1963.htm

Transportation Research Board, 1991. Highway deicing, comparing salt and Calcium Magnesium Acetate, chapter 2: road salt use in the United States. National Research Council. Retrieved from: 
http://onlinepubs.trb.org/onlinepubs/sr/sr235/017-030.pdf.

Tsolaki, E., Diamadopoulos, E., 2010. Technologies for ballast water treatment: a review. Journal of Chemical technology and Biotechnology 85: 19-32.

University of California. 2009. West coast ballast outreach project. Retrieved from: http://groups.ucanr.org/Ballast_Outreach/Ballast_Management_Research_and_Treatment_Technology/Treatment_Technology_Approval_ Process.htm

Verling, E., Ruiz, G.M., Smith, L.D., Galil, B., Miller, A.W., Murphy, K.R., 2005. Supply-side invasion ecology: characterizing propagule pressure in coastal ecosystems. Proceedings of the Royal Society B. 272: 1249-1256.

Wallace, E.L. 2002. Rotifers: exquisite metazoans. Integrative and Comparative Biology 42: 660-667.

Wells, M., Bailey, S.A., Ruddick, B., 2010. The dilution and dispersion of ballast water discharged into Goderich Harbor. Marine Pollution Bulletin. In revision.

Williamson, M., Brown, K.C. 1986. The analysis and modeling of British invasions. Philosophical Transactions of the Royal Society of London Series B, Biological Sciences 314: 505-522.

Wonham, M.J., Lewis, M.A., Maclsaac, H.J. 2005. Minimizing invasion risky reducing propagule pressure: a model for ballast-water exchange. Frontiers in Ecology and the Environment 3: 473-478.

Yurista, P.M., Schulz, K.L. 1995. Bioenergetic analysis of prey consumption by Bythotrephes cederstroemi in Lake Michigan. Canadian Journal of Fisheries and Aquatic Sciences 52: 141-150. 
Appendix 1. List of zooplankton species recorded from ballasted and residual ballast experiments.

Ballasted vessel 1

\begin{tabular}{|c|c|c|c|c|c|}
\hline Control & 0 & 1 & 10 & 25 & 44 \\
\hline \multicolumn{6}{|l|}{ Copepoda } \\
\hline Calanoid & 160 & 680 & 770 & 710 & 3433 \\
\hline Cyclopoid & 110 & 1040 & 610 & 650 & 4033 \\
\hline Harpacticoid & 70 & 570 & 310 & 110 & 1533 \\
\hline Nauplii & 30 & 230 & 100 & 150 & 167 \\
\hline \multicolumn{6}{|l|}{ Cladocera } \\
\hline Daphnia & 10 & 210 & 40 & 190 & 267 \\
\hline Bosmina & 270 & 1230 & 520 & 630 & 6567 \\
\hline Diaphanosoma & 10 & 40 & 0 & 0 & 0 \\
\hline Bythotrephes & 0 & 0 & 0 & 0 & 0 \\
\hline \multicolumn{6}{|l|}{ Rotifera } \\
\hline All rotifers & 290 & 4530 & 2130 & 1970 & 19800 \\
\hline $\begin{array}{l}\text { Other (Annelid, } \\
\text { insect, mollusc) }\end{array}$ & 60 & 70 & 30 & 50 & 33 \\
\hline \multicolumn{6}{|l|}{ Treatment } \\
\hline \multicolumn{6}{|l|}{ Copepoda } \\
\hline Calanoid & 115 & 7 & 2 & 0 & 0 \\
\hline Cyclopoid & 132 & 3 & 1 & 0 & 0 \\
\hline Harpacticoid & 41 & 0 & 0 & 0 & 0 \\
\hline Nauplii & 16 & 0 & 0 & 0 & 0 \\
\hline \multicolumn{6}{|l|}{ Cladocera } \\
\hline Daphnia & 12 & 0 & 0 & 0 & 0 \\
\hline Bosmina & 157 & 5 & 4 & 0 & 0 \\
\hline Diaphanosoma & 2 & 0 & 0 & 0 & 0 \\
\hline Bythotrephes & 0 & 0 & 0 & 0 & 0 \\
\hline \multicolumn{6}{|l|}{ Rotifera } \\
\hline All rotifers & 520 & 16 & 2 & 0 & 0 \\
\hline $\begin{array}{l}\text { Other (Annelid, } \\
\text { insect, mollusc) }\end{array}$ & 5 & 0 & 1 & 0 & 0 \\
\hline
\end{tabular}

Ballasted vessel 2

\begin{tabular}{|c|c|c|c|c|c|}
\hline Control & 0 & 1 & 10 & 25 & 44 \\
\hline Copepoda & & & & & \\
\hline Calanoid & 20 & 17 & 11 & 12 & 17 \\
\hline Cyclopoid & 37 & 41 & 35 & 26 & 24 \\
\hline Harpacticoid & 19 & 23 & 13 & 13 & 17 \\
\hline
\end{tabular}




\begin{tabular}{|c|c|c|c|c|c|}
\hline Nauplii & 6 & 10 & 4 & 6 & 5 \\
\hline \multicolumn{6}{|l|}{ Cladocera } \\
\hline Daphnia & 6 & 6 & 0 & 0 & 2 \\
\hline Bosmina & 51 & 62 & 45 & 38 & 48 \\
\hline Diaphanosoma & 0 & 0 & 0 & 0 & 0 \\
\hline Bythotrephes & 15 & 11 & 12 & 11 & 11 \\
\hline \multicolumn{6}{|l|}{ Rotifera } \\
\hline All rotifers & 170 & 142 & 120 & 129 & 134 \\
\hline $\begin{array}{l}\text { Other (Annelid, } \\
\text { insect, mollusc) }\end{array}$ & 32 & 27 & 22 & 21 & 24 \\
\hline \multicolumn{6}{|l|}{ Treatment } \\
\hline \multicolumn{6}{|l|}{ Copepoda } \\
\hline Calanoid & 41 & 2 & 0 & 0 & 0 \\
\hline Cyclopoid & 15 & 2 & 2 & 0 & 0 \\
\hline Harpacticoid & 30 & 0 & 0 & 0 & 0 \\
\hline Nauplii & 8 & 1 & 0 & 0 & 0 \\
\hline \multicolumn{6}{|l|}{ Cladocera } \\
\hline Daphnia & 0 & 0 & 0 & 0 & 0 \\
\hline Bosmina & 11 & 3 & 0 & 0 & 0 \\
\hline Diaphanosoma & 0 & 0 & 0 & 0 & 0 \\
\hline Bythotrephes & 8 & 0 & 0 & 0 & 0 \\
\hline \multicolumn{6}{|l|}{ Rotifera } \\
\hline All rotifers & 78 & 3 & 1 & 0 & 0 \\
\hline $\begin{array}{l}\text { Other (Annelid, } \\
\text { insect, mollusc) }\end{array}$ & 5 & 1 & 0 & 0 & 0 \\
\hline
\end{tabular}

Ballasted vessel 3

\begin{tabular}{|c|c|c|c|c|c|}
\hline Control & 0 & 1 & 10 & 25 & 44 \\
\hline Copepoda & & & & & \\
\hline Calanoid & 26 & 3 & 7 & 11 & 22 \\
\hline Cyclopoid & 16 & 4 & 5 & 15 & 27 \\
\hline Harpacticoid & 3 & 1 & 3 & 6 & 13 \\
\hline Nauplii & 4 & 0 & 1 & 7 & 28 \\
\hline Cladocera & & & & & \\
\hline Daphnia & 0 & 1 & 0 & 2 & 2 \\
\hline Bosmina & 22 & 11 & 12 & 16 & 31 \\
\hline Diaphanosoma & 0 & 0 & 0 & 0 & 0 \\
\hline Bythotrephes & 4 & 0 & 0 & 3 & 4 \\
\hline Rotifera & & & & & \\
\hline All rotifers & 23 & 16 & 16 & 27 & 59 \\
\hline $\begin{array}{c}\text { Other (Annelid, } \\
\text { insect, mollusc) }\end{array}$ & 7 & 2 & 7 & 11 & 30 \\
\hline & & & & & \\
\hline Treatment & & & & & \\
\hline
\end{tabular}




\begin{tabular}{|c|c|c|c|c|c|}
\hline Copepoda & & & & & \\
\hline Calanoid & 7 & 1 & 0 & 0 & 0 \\
\hline Cyclopoid & 10 & 2 & 0 & 0 & 0 \\
\hline Harpacticoid & 2 & 0 & 0 & 0 & 0 \\
\hline Nauplii & 2 & 0 & 0 & 0 & 0 \\
\hline Cladocera & & & & & \\
\hline Daphnia & 1 & 0 & 0 & 0 & 0 \\
\hline Bosmina & 17 & 2 & 0 & 0 & 0 \\
\hline Diaphanosoma & 0 & 0 & 0 & 0 & 0 \\
\hline Bythotrephes & 2 & 0 & 0 & 0 & 0 \\
\hline Rotifera & & & & & 0 \\
\hline All rotifers & 28 & 6 & 4 & 0 & 0 \\
\hline $\begin{array}{c}\text { Other (Annelid, } \\
\text { insect, mollusc) }\end{array}$ & 2 & 1 & 0 & 0 & 0 \\
\hline
\end{tabular}

\section{Residual ballast 1}

\begin{tabular}{|c|c|c|c|c|}
\hline Control & 0 & 1 & 2 & 3 \\
\hline \multicolumn{5}{|l|}{ Copepoda } \\
\hline Calanoid & 0 & 1 & 0 & 1 \\
\hline Cyclopoid & 2 & 1 & 2 & 2 \\
\hline Harpacticoid & 0 & 0 & 1 & 1 \\
\hline Nauplii & 2 & 2 & 3 & 2 \\
\hline \multicolumn{5}{|l|}{ Cladocera } \\
\hline Daphnia & 0 & 2 & 0 & 0 \\
\hline Bosmina & 0 & 1 & 2 & 2 \\
\hline Diaphanosoma & 0 & 0 & 0 & 0 \\
\hline Bythotrephes & 0 & 0 & 0 & 0 \\
\hline \multicolumn{5}{|l|}{ Rotifera } \\
\hline All rotifers & 15 & 12 & 14 & 22 \\
\hline $\begin{array}{l}\text { Other (Annelid, } \\
\text { insect, mollusc) }\end{array}$ & 3 & 3 & 4 & 4 \\
\hline \multicolumn{5}{|l|}{ Treatment } \\
\hline \multicolumn{5}{|l|}{ Copepoda } \\
\hline Calanoid & 0 & 0 & 0 & 0 \\
\hline Cyclopoid & 1 & 0 & 0 & 0 \\
\hline Harpacticoid & 0 & 0 & 0 & 0 \\
\hline Nauplii & 1 & 0 & 0 & 0 \\
\hline \multicolumn{5}{|l|}{ Cladocera } \\
\hline Daphnia & 0 & 0 & 0 & 0 \\
\hline Bosmina & 0 & 0 & 0 & 0 \\
\hline Diaphanosoma & 0 & 0 & 0 & 0 \\
\hline Bythotrephes & 0 & 0 & 0 & 0 \\
\hline \multicolumn{5}{|l|}{ Rotifera } \\
\hline All rotifers & 6 & 0 & 0 & 0 \\
\hline
\end{tabular}




\begin{tabular}{|c|c|c|c|c|}
\hline $\begin{array}{c}\text { Other (Annelid, } \\
\text { insect, mollusc) }\end{array}$ & 2 & 0 & 0 & 0 \\
\hline
\end{tabular}

Residual ballast 2

\begin{tabular}{|c|c|c|c|c|}
\hline Control & 0 & 1 & 2 & 3 \\
\hline Copepoda & & & & \\
\hline Calanoid & 9 & 28 & 46 & \\
\hline Cyclopoid & 14 & 33 & 37 & \\
\hline Harpacticoid & 7 & 17 & 8 & \\
\hline Nauplii & 23 & 21 & 22 & \\
\hline Cladocera & & & & \\
\hline Daphnia & 2 & 13 & 14 & \\
\hline Bosmina & 12 & 117 & 114 & \\
\hline Diaphanosoma & 2 & 2 & 1 & \\
\hline Bythotrephes & 0 & 0 & 0 & \\
\hline Rotifera & & & & \\
\hline All rotifers & 118 & 190 & 192 & \\
\hline $\begin{array}{c}\text { Other (Annelid, } \\
\text { insect, mollusc) }\end{array}$ & 17 & 31 & 33 & \\
\hline Treatment & & & & \\
\hline Copepoda & & & & 0 \\
\hline Calanoid & 0 & 4 & 2 & 0 \\
\hline Cyclopoid & 0 & 4 & 3 & 0 \\
\hline Harpacticoid & 0 & 2 & 0 & 0 \\
\hline Nauplii & 4 & 11 & 9 & 0 \\
\hline Cladocera & & & & 0 \\
\hline Daphnia & 0 & 0 & 0 & 0 \\
\hline Bosmina & 5 & 22 & 10 & 0 \\
\hline Diaphanosoma & 0 & 1 & 0 & 0 \\
\hline Bythotrephes & 0 & 0 & 0 & 0 \\
\hline Rotifera & & & & 0 \\
\hline All rotifers & 31 & 138 & 91 & \\
\hline $\begin{array}{c}\text { Other (Annelid, } \\
\text { insect, mollusc) }\end{array}$ & 2 & 26 & & \\
\hline
\end{tabular}

Residual ballast 3

\begin{tabular}{|c|c|c|c|}
\hline Control & 0 & 1 & 2 \\
\hline Copepoda & & & 4 \\
\hline Calanoid & 4 & 6 & 7 \\
\hline Cyclopoid & 3 & 12 & 2 \\
\hline Harpacticoid & 0 & 2 & 9 \\
\hline Nauplii & 10 & 8 & 0 \\
\hline Cladocera & & & \\
\hline Daphnia & 2 & 4 & \\
\hline
\end{tabular}




\begin{tabular}{|c|c|c|c|}
\hline Bosmina & 52 & 35 & 24 \\
\hline Diaphanosoma & 0 & 0 & 0 \\
\hline Bythotrephes & 0 & 0 & 0 \\
\hline Rotifera & & & 60 \\
\hline All rotifers & 146 & 93 & 13 \\
\hline $\begin{array}{c}\text { Other (Annelid, insect, } \\
\text { mollusc) }\end{array}$ & 17 & 12 & \\
\hline Treatment & & & 0 \\
\hline Copepoda & & & 0 \\
\hline Calanoid & 6 & 0 & 0 \\
\hline Cyclopoid & 21 & 0 & 0 \\
\hline Harpacticoid & 8 & 0 & 0 \\
\hline Nauplii & 19 & 0 & 0 \\
\hline Cladocera & & & 0 \\
\hline Daphnia & 0 & 0 & 0 \\
\hline Bosmina & 37 & 0 & 0 \\
\hline Diaphanosoma & 0 & 0 & 0 \\
\hline Bythotrephes & 0 & 0 & 0 \\
\hline Rotifera & & & \\
\hline All rotifers & 158 & & \\
\hline $\begin{array}{c}\text { Other (Annelid, insect, } \\
\text { mollusc) }\end{array}$ & 23 & & 0 \\
\hline
\end{tabular}




\section{Vita Auctoris}

Name:

Place of birth:

Hometown:

Education:
Tony Nan-Chun Wang

Tainan, Taiwan

Brampton, Ontario, Canada

North Park Secondary School, Brampton, Ontario 2000- 2004, Grade 12 Diploma, Ontario Academic Credits

University of Guelph, Guelph, Ontario 2004-2008, Honours BSc Marine and Freshwater Biology

Great Lakes Institute for Environmental Research, University of Windsor, Windsor, Ontario, 2008-2010, MSc Environmental Science 